\title{
BUDAYA DAN KEARIFAN LOKAL KERAJAAN INSANA DI DATARAN TIMOR
}

\author{
Faizal Arvianto $^{1 *}$, Giri Indra Kharisma ${ }^{1}$ \\ ${ }^{1}$ Universitas Timor, Indonesia \\ *e-mail: faizal arvianto@unimor.ac.id
}

\begin{abstract}
Abstrak
Pada era globalisasi pengetahuan masyarat tentang kerajaan di masa lampau menjadi semakin terbatas. Minimnya literatur tertulis yang mengungkapkan keanekaragaman kerajaan di masa lampau menjadi salah satu penyebabnya. Hal ini dapat dijumpai pada kerajaan-kerajaan di dataran Timor tepatnya di Kabupaten Timor Tengah Utara seperti kerajaan Insana yang dipimpin klan Us Finit, Kerajaan Biboki oleh klan Us Boko, dan Kerajaan Amarasi oleh klan Koroh. Dalam perkembangannya, sumber informasi tradisi dan budaya yang diketahui sampai sekarang masih berasal dari cerita rakyat dan tradisi yang berkembang turun-temurun. Penelitian untuk mengungkap budaya dan kearifan lokal Kerajaan Insana di Dataran Timor. Penelitian ini menggunakan metode deskriptif kualitatif dan dilaksanakan di Oelolok, Desa Ainiut, Kecamatan Insana, Kabupaten Timor Tengah Utara, Provinsi Nusa Tenggara Timur. Instrumen penelitian yang digunakan berupa: panduan wawancara, observasi, dan dokumentasi. Berdasarkan hasil penelitian, disimpulkan bahwa kebudayaan dan kearifan lokal yang ada di kerajaan Insana cukup beragam. Dari segi budaya, terdapat beberapa kesenian dan kerajinan yang ada di kerajaan Insana. Ragam budaya yang ada pada masyarakat Insana juga telah melahirkan kearifan lokal yang sudah diwariskan secara tutun temurun. Kearifan lokal tersebut dapat terlihat pada upacara ritual dan tradisi yang menjadi adat istiadat masyarakat Insana.
\end{abstract}

Kata Kunci: Budaya; Kearifan Lokal; Insana

\begin{abstract}
In the era of globalization, public knowledge about past kingdoms has become increasingly limited. The lack of written literature that reveals the diversity of the past kingdoms is one of the reasons. This can be found in the kingdoms on the plains of Timor, to be precise in North Central Timor Regency, such as the Insana kingdom led by the Us Finit clan, the Biboki kingdom by the Us Boko clan, and the Amarasi Kingdom by the Koroh clan. The sources of information on traditions and culture still come from folk tales and traditions developed from generation to generation. The research aim is to study the culture and local wisdom of the Insana Kingdom on the Plains of Timor". This research used a qualitative descriptive method and was carried out in Oelolok, Ainiut Village, Insana District, North Central Timor Regency, East Nusa Tenggara Province. The research instruments used were: interview guides, observation, and documentation. Based on the research results, it was concluded that the culture and local wisdom in the Insana kingdom were quite diverse. From a cultural perspective, there are several arts and crafts in the Insana kingdom. The cultural diversity in the Insana community has also given birth to local wisdom passed down from generation to generation. This local wisdom can be seen in the rituals and traditions that have become the Insana people's customs.
\end{abstract}

Keywords: Culture; Local Wisdom; Insana

This is an open access article under the CC BY-SA license.

Copyright (C) 2021 by Author. Published by Universitas Pendidikan Ganesha.

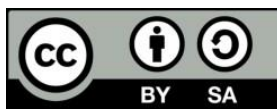




\section{PENDAHULUAN}

Suatu permukiman terbentuk dari kumpulan individu yang tinggal dalam suatu wilayah yang kemudian membentuk sebuah kelompok. Kelompok yang berada di permukiman tidak lepas dari adanya seorang pemimpin. Dari adanya pemimpin itulah kemudian memunculkan untuk membuat kelompok yang lebih besar seperti klan, suku, maupun kerajaan. Hal ini dapat dijumpai dalam kerajaankerajaan di dataran Timor tepatnya di Kabupaten Timor Tengah Utara seperti kerajaan Insana yang dipimpin klan Us Finit, Kerajaan Biboki oleh klan Us Boko, dan Kerajaan Amarasi oleh klan Koroh. Salah satu wilayah dengan ciri kerajaan di dataran Timor yang berbeda dari wlayah lain adalah wilayah Insana. Hal ini dikarenakan wilayah Insana mempunya sonaf (kerajaan) yang mempunyai struktur bangunan dan pemerintahan yang berbeda dengan kerajaan lain. Wilayah Insana terletak di Kabupaten Timor Tengah Utara tepatnya di Kota Kefamenanu bagian Tengah dan dahulu dikuasa oleh Raja Us Finit.

Masyarakat Insana dikenal sebagai masyarakat yang masih asli susunannya, khususnya bila dibandingkan dengan kerajaankerajaan lainnya di Timor yang telah banyak mengalami perubahan terutama sejak pembentukan desa gaya baru pada era 1960-an. Masyarakatnya tersusun dalam suatu struktur adat berjenjang, yang terdiri dari raja-raja, suku-suku, serta rakyat biasa. Adat istiadat dan ritus Insana juga masih terpelihara dengan baik, misalnya upacara pengumpulan upeti, upacara kematian raja-raja, upacara potong rarnbut bayi, upacara rumah adat, upacara bercocok tanam, dan lain-lain, walaupun pada saat ini beberapa ritual yang tidak dilaksanakan lagi.

Pada era globalisasi seperti sekarang ini, pengetahuan masyarat tentang kerajaan di masa lampau menjadi semakin terbatas. Minimnya literatur atau sumber informasi tertulis yang mengungkapkan keanekaragaman kerajaan-kerajaan di masa lampau menjadi salah satu penyebabnya. Sumber-sumber informasi tertulis yang selama ini menginformasikan tentang kerajaankerajaan di Kabupaten Timor Tengah Utara, Provinsi Nusa Tenggara Timur dari awal munculnya peradaban sampai datangnya bangsa Barat hampir tidak ada. Hal ini ditunjang oleh keberadaan prasasti yang kurang dikenal di daerah ini. Dalam perkembangannya, sumber tradisi dan budaya yang diketahui sampai sekarang masih berasal dari cerita rakyat dan tradisi yang berkembang turun-temurun.

Berdasarkan kenyataan tersebut, muncullah beberapa masalah yang krusial tidak disadari oleh pada masyarakat umumnya dan masyarakat di wilayah Insana pada khususnya. Misalnya belum adanya pemetaan dan identifikasi budaya maupun kearifan lokal yang dimiliki oleh masyarakat di wilayah Insana, kurangnya andil masyarakat dalam publikasi dan pelestarian situs budaya di wilayah Insana, serta dokumentasi mengenai tradisi dan budaya di wilayah Insana. Oleh karenanya, penulis tertarik untuk melakukan penelitian kualitatif tentang sebuah kerajaan di wilayah Insana dengan judul "Budaya dan Kearifan Lokal Kerajaan Insana di Dataran 
Timor". Berdasarkan dari latar belakang tersebut, maka tujuan penelitian ini adalah untuk mengidentifikasi dan mendeskripsikan budaya dan kearifan lokal yang ada pada Kerajaan Insana sebagai salah satu kerajaan yang ada di dataran Timor.

Budaya adalah suatu cara hidup yang berkembang dan dimiliki bersama oleh sebuah kelompok orang dan diwariskan dari generasi ke generasi. Budaya terbentuk dari banyak unsur yang rumit, termasuk sistem agama dan politik, adat istiadat, bahasa, perkakas, pakaian, bangunan, dan karya seni. Budaya adalah suatu pola hidup menyeluruh. Budaya bersifat kompleks, abstrak, dan luas. Banyak aspek budaya turut menentukan perilaku komunikatif. Unsur-unsur sosio-budaya ini tersebar dan meliputi banyak kegiatan sosial manusia.

Selo Soemardjan dan Soelaeman Somardi dalam Soekanto (2006) merumuskan "kebudayaan sebagai semua hasil karya, rasa dan cipta masyarakat. Selanjutnya Koentjaraningrat menjabarkan buadaya dari asal arti tersebut yaitu "colere" dan kemudian "culture" diartikan sebagai segala daya dan kegiatan manusia untuk mengolah dan mengubah alam (dalam Soekanto, 2006). Berbeda dengan Koentjaraningrat, menurut Linton budaya adalah keseluruhan sikap \& pola perilaku serta pengetahuan yang merupakan suatu kebiasaan yang diwariskan \& dimilik oleh suatu anggota masyarakat tertentu.

Terdapat beberapa pendapat ahli mengenai komponen atau unsur kebudayaan atau budaya yaitu sebagai berikut; Melville J. Herkovits, menyebutkan kebudayaan memiliki 4 unsur pokok yaitu: alat-alat teknologi, sistem ekonomi keluarga, kekuasaan politik. Berbeda dengan Herkovits, Kluckhohn menyatakan bahwa terdapat tujuh unsur budaya atau kebudayaan yang sifatnya secara universal yaitu; bahasa, sistem pengetahuan, sistem teknologi, dan peralatan, sistem kesenian, sistem mata pencaharian hidup, sistem religi.

Berdasarkan dari beberapa unsur budaya yang dikemukakan oleh para ahli maka dapat ditarik kesimpulan bahwa unsur-unsur kebudayaan adalah sebagai berikut; perilaku-perilaku tertentu, gaya berpakaian, kebiasaankebiasaan, adat istiadat, kepercayaan, dan tradisi.

Suparman mengemukakan kearifan lokal adalah sebagian bentuk dari tradisi dan budaya yang mempunyai nilai-nilai luhur dan sudah diajarkan sejak lama secara turun temurun. Semua bentuk pengetahuan, keyakinan, pemahaman, atau wawasan serta adat kebiasaan atau etika yang menuntun perilaku manusia dalam kehidupan di dalam komunitas ekologis. Kearifan lokal adalah sumber pengetahuan yang diselenggarakan dinamis, berkembang, dan diteruskan oleh produksi populasi tertentu yang terintegrasi dengan pemahaman terhadap alam dan budaya sekitanya. Kearifan lokal adalah dasar untuk pengambilan kebijakan pada tingkal lokal dibidang kesehatan, pertanian, pendidikan, pengelolaan sumber daya alam dan kegiatan masyarakat pedesaan.

Menurut Aminudin (2013) pengertian kearifan lokal terdiri dari dua kata, yaitu kearifan (wisdom) dan lokal 
(local). Lokal yang berarti setempat, sementara wisdom berarti kebijaksanaan. Dengan demikian, kearifan lokal merupakan gagasangagasan atau nilai-nilai, pandangan setempat atau (lokal) yang bersifat bijaksana, penuh kearifan, bernilai baik yang tertanam dan diikuti oleh anggota masyarakatnya. Sejalan dengan hal tersebut, Syani (2013) menjelaskan bahwa secara etimologis, kearifan (wisdom) berarti kemampuan seseorang dalam menggunakan akal pikirannya untuk menyikapi sesuatu kejadian, obyek atau situasi, sedangkan lokal, menunjukkan ruang interaksi di mana peristiwa atau situasi tersebut terjadi. Dengan demikian, kearifan lokal secara substansial merupakan nilai dan norma yang berlaku dalam suatu masyarakat yang diyakini kebenarannya dan menjadi acuan dalam bertindak dan berperilaku sehari-hari. Dengan kata lain kearifan lokal adalah kemampuan menyikapi dan memberdayakan potensi nilai-nilai luhur budaya setempat.

\section{METODE}

Berdasarkan masalah penelitian yang dirumuskan maka penelitian ini menggunakan metode deskriptif kualitatif. Menurut Sukmadinata (2008) penelitian deskriptif merupakan penelitian yang mendeskripsikan atau menggambarkan fenomena-fenomena yang ada, baik fenomena yang bersifat alamiah ataupun rekayasa manusia. Penelitian deskriptif merupakan penelitian yang hanya menggambarkan apa adanya tentang suatu variabel, gejala ataupun keadaan (Arikunto, 2003).
Penelitian ini dilaksanakan di Oelolok, Desa Ainiut, Kecamatan Insana, Kabupaten Timor Tengah Utara, Provinsi Nusa Tenggara Timur. Penelitian ini mengidentifikasi dan mendeskripsikan budaya dan kearifan lokal yang ada pada Kerajaan Insana. Instrumen yang digunakan sebagai alat untuk mengumpulkan data yaitu berupa: panduan wawancara, observasi, dan dokumentasi. Data yang telah diperoleh akan dianalisis secara kualitatif serta diuraikan dalam bentuk deskriptif. Teknik analisis data yang digunakan dalam penelitian ini adalah menggunakan langkah-langkah seperti yang dikemukakan oleh Levi's Straus dalam Bungin (2003), yaitu: pengumpulan data, yang merupakan bagian integral dari kegiatan analisis data. Kegiatan pengumpulan data pada penelitian ini adalah dengan menggunakan wawancara dan studi dokumentasi.

Berikutnya adalah reduksi data, diartikan sebagai proses pemilihan, pemusatan perhatian pada penyederhanaan dan transformasi data kasar yang muncul dari catatan-catatan tertulis di lapangan. Reduksi dilakukan sejak pengumpulan data dimulai dengan membuat ringkasan, mengkode, menelusur tema, membuat gugus-gugus, menulis memo dan sebagainya dengan maksud menyisihkan data/informasi yang tidak relevan. Selanjutnya adalah display data, yang merupakan langkah pendeskripsian sekumpulan informasi tersusun yang memberikan kemungkinan adanya penarikan kesimpulan dan pengambilan tindakan. Penyajian data kualitatif disajikan dalam bentuk teks naratif. 
Penyajiannya juga dapat berbentuk matrik, diagram, tabel, dan bangun. Pada bagian akhir analisis data adalah verifikasi dan penegasan kesimpulan. Langkah ini merupakan kegiatan akhir dari analisis data. Penarikan kesimpulan berupa kegiatan interpretasi, yaitu menemukan makna data yang telah disajikan.

\section{HASIL DAN PEMBAHASAN}

\section{Geografi dan Kependudukan Kerajaan Insana}

Wilayah Kerajaan Insana, yang sekarang dikenal dengan Kecamatan Insana, terletak di tengah Pulau Timor, tepatnya di Kabupaten Timor Tengah Utara (TTU). Daerahnya berbentuk seperti kantong yang bermuara ke pantai utara di Laut Sawu (Tasifeto), di mana ada pelabuhan Wini yang dulunya bernama Mena. Wilayah Insana terdiri atas dataran yang luas dengan padang rumput (sabana) dan perbukitan di bagian tengah, di mana terletak bukit Maubes, bukit Fafinesu dan Humus di dekat pantai utara yang banyak ditumbuhi pohon kayu putih (eucalyptus alba), serta bukit-bukit di sebelah timur yang menjadi perbatasan dengan Biboki (Oken-Neonbat) dan Belu (Loiram, Ainiut).

Pada bagian tengah wilayah Insana mengalir sungai Maubesi dan sungai Bijau yangbermuara ke Benenai di Belu Selatan. Di bagian utara mengalir sungai Mausak yang bermuara ke Mena, pantai utara. Di pantai utara ada bekas pelabuhan Mena yang terkenal sejak dulu untuk perdagangan kayu cendana dan lilin. Pelabuhan tersebut ekarang dipindah ke sebelah baratnya, tepatnya di Wini, yang berfungsi sebagai pelabuhan hewan.

Masyarakat mernanfaatkan padang rumput untuk bertani dan berkebun sebagai mata pencaharian utama. Mereka juga beternak sapi, kerbau, kambing, babi, ayam dan unggas lain. Hutan di wilayah Insana terdiri dari banyak pohon cendana (sandalwood, Santalana album) serta kayu matani atau kayu merah (pterocarpus indicum) dan sekarang banyak ditanami kayu jati (tectona grandis). Kayu cendana, kayu kuning, asam, dan madu merupakan hasil hutan yang sering diperdagangkan masyarakat Insana.

Daerah dataran rendah di Insana banyak ditumbuhi oleh pohon tuak (borassus flabellifar) yang niranya diolah menjadi gula merah dan sopi (arak). Di wilayah Insana, sopi merupakan produk yang penting karena merupakan sarana perlengkapan pada upacara-upacara adat maupun acaraacara lainnya. Iklim di wilayah Insana terdiri atas musim kering dari April hingga November, dan musim hujan dari November hingga April. Pada musim hujan masyarakat berladang atau bersawah, sedangkan pada rnusim panas biasanya mereka rnembersihkan kebun, menebas hutan untuk berkebun, dan mengiris tuak (lontar) untuk mernbuat gula merah, gula air, dan sopi.

\section{Ras dan Suku}

Pulau Timor adalah sebuah wilayah transisi. Penduduknya merupakan campuran antara ProtoMelayu dan Melanesia. Wilayah Insana didiami oleh orang Dawan atau Atoni (melanesia). Di wilayah perbatasan 
dengan Belu penduduknya berkulit lebih terang karena telah terjadi percampuran dengan ras lain, bahkan dengan ras Cina dan Portugis. Pada umumnya, dapat dikatakan bahwa orang Insana merupakan peralihan antara orang Belu dan Dawan. Perawakannya sedang sampai tinggi, berambut ombak sampai lurus, dengan ukuran kepala bracchi cephalic (Usfinit, 2003).

Masyarakat Insana hidup berkelompok dalam suatu suku atau klan yang mempunyai tugas-tugas tertentu, mempunyai adat istiadat sendiri, dan tinggal di suatu wilayah tertentu. Tiap suku mempunyai cabang atau subklan. Suku-suku pada umumnya terbagi atas tiga kelompok besar, yaitu usif, amaf, dan kolo manu. Nama suku diturunkan menurut garis ayah (patrilineal). Usif adalah kelompok suku yang berstatus bangsawan dan mempunyai beberapa suku rakyat (amaf) di bawahnya sebagai pendamping, pembantu, pemberi upeti (maus) dari panglima perangnya. Usif bertingkat-tingkat mulai dari rendah, sedang, hingga tinggi, sesuai dengan jumlah suku amaf di bawahnya dan sesuai luas wilayah yang dikuasainya.

Usif di Insana terbagi atas usif tertinggi (Usfinit), usif besar dalam (Kolne, Abainpah, Manikin, Maun Naijuf), usif besar luar (Us Fal, Us Taolin, Us Pupu, Us Tonbes), usif menetap (Balnai, Kisnai, Hoinnai, Tefnai), usif tengah (Ataupah, Anapah, Abainpah, Afeanpah), usif penerang (Taku, Talua, Asolan, Akunut), dan usif kecil lain (Noe Tnana, Us Subun, Laemfaun, Ahoinpah, dan lainnya). Amaf adalah kelompok suku yang terdiri atas suku besar (amaf naek), suku-suku kecil pendamping (amaf ana atau nefu hala), penjaga tanah (tobe kalili), dan suku-suku kecil (kanaf). Suku amaf diketuai secara adat oleh kapitan (kepala suku besar), amnasit (kepala suku), dan nakaf (kepala suku kecil), yang biasanya hidup berkelompok di suatu wilayah bersama dengan usif mereka. Kelompokkelompok masyarakat tinggal dan hidup bersama dalam sebuah kuan (kampung) dengan kepala pemerintahannya yang disebut temukung. Beberapa kampung dikelompokkan dalam kefetoran, yang dipimpin oleh seorang usif yang disebut fetor.

Kolo manu adalah kelompok masyarakat biasa, yang biasanya bertugas sebagai pekerja ladang atau penjaga ternak, Di samping itu, masih ada kelompok masyarakat yang disebut abeat atau ate, yaitu kelompok masyarakat yang dirampas atau dibeli sewaktu perang dan kemudian dijadikan hamba/budak. Namun, pada masa modern seperti sekarang ini, abeat sudah tidak ada lagi.

\section{Bahasa}

Bahasa sehari-hari yang digunakan masyarakat Insana adalah bahasa Dawan. Beberapa masayarakt yang tinggal di sekitar perbatasan Belu juga menggunakan bahasa Tetum. Ada juga bahasa Dawan yang memiliki dialek khusus seperti Dawan Amarasi, yang mengganti konsonan "l" dengan "r". Bahasa Dawan adalah bahasa yang mempunyai konjugasi atau perubahan bentuk kata kerja menurut subjek pelakunya, mempunyai tingkatantingkatan ungkapan bahasa (halus dan kasar) menurut tinggi rendahnya

Jurnal IImu Sosial dan Humaniora | 122 
kedudukan lawan bicara, serta banyak menggunakan konsonan dan tekanantekanan yang tegas di tengah kata (Usfinit, 2003). Perbedaan tekanan dapat menyebabkan perbedaan makna, misalnya amo'et berarti "pembuat/pencipta" sedangkan amoet berarti "pemalu". Contoh konjugasi kata kerja adalah pada kata mua (ua) yang berarti "makan".

$\begin{array}{ll}\text { au ua } & \text { : saya makan } \\ \text { ho mua } & \text { : engkau makan } \\ \text { in nah } & \text { : dia makan } \\ \text { hai mia } & \text { : kami makan } \\ \text { hit tah } & \text { : kita makan } \\ \text { hi mia } & \text { : kalian makan }\end{array}$

Pada umumnya, ada empat tingkatan bahasa menurut rasa kehalusannya. Sebagai contoh, untuk kata mua (ua) terdapat tingkatan berikut:

- ua: digunakan untuk bahasa seharihari;

- bukae: digunakan untuk tamu dan orang yang lebih tua, lebih tinggi kedudukannya, atau dihormati;

- ta'nam'ok: digunakan khusus untuk raja-raja; dan

- ta'futu': digunakan dalam syair, bahasa tutur adat, khusus untuk para amaf.

Dalam mengucapkan tutur adat (takanab), bahasa yang digunakan adalah bahasa takanab sesuai tingkatan tersebut di atas, yang semua ungkapannya penuh dengan kiasankiasan. Dernikian pula dalam rapatrapat adat selalu digunakan bahasa tingkat tinggi serta kata-kata konotatif dan kadang-kadang hanya diumpamakan saja (makle'at).
Budaya Kerajaan Insana

Masyarakat Insana mempunyai kesenian dan kerajinan yang khas. Setiap upacara atau kegiatan seharihari selalu disertai dengan gerak dan tari serta pakaian dengan perlengkapan-perlengkapan yang khas Kerajaan Insana. Kesenian dan kerajinan Insana cukup dikenal di dataran Timor. Hingga kini, masyarakatnya kerap diminta untuk mewakili Kabupaten TTU dan Propinsi Nusa Tenggara Timur dalam acara penyambutan tamu ataupun festivalfestival di daerah maupun tingkat nasional.

\section{Seni Tari}

Jenis tarian masyarakat Insana sangat beragam sesuai dengan suasana dan peristiwa yang dialami. Misalnya, ada tarian yang bersifat heroik dan gernbira sebagai ungkapan memenangkan perang atau suasana pesta, ada pula tarian yang bersuasana sedih. Masing-masing jenis tarian diiringi dengan alat musik tersendiri. Tari perang (tabso, bso'ot), yang dahulu biasanya dilaksanakan setelah memenangkan perang atau pada saat pesta rumah adat, selalu dipertunjukkan oleh para penari dengan perlengkapan perang. Tarian ini dilengkapi dengan giring-giring dan sering dimainkan secara berpasangan. Hentakan kaki para penari disesuaikan dengan irama pukulan gong. Para penari pada umumnya kaum laki-laki yang dilengkapi dengan senjata perangnya berupa tombak dan kelewang. Sambil menari, mereka memainkan dan rnemutar-mutar senjatanya. Boen Helen dan Tiban adalah tarian perang untuk menyambut 
pahlawan perang yang pulang dengan membawa kepala musuh. Alat musik yang mengiringi tari perang terdiri atas lima buah gong (senne) dengan bermacam-rnacam ukuran serta gendang, yang semuanya ditabuh dengan penuh semangat oleh ibu-ibu. Pada zaman dulu, sebelum ada gong dari logam, alat musiknya dibuat dari bambu (sen oba). Jenis dan ragam pukulan membedakan sentakansentakan kaki dengan giring-giringnya.

Tari bidu (biul) biasanya
dibawakan oleh gadis-gadis atau ibuibu. Sekarang tarian ini sudah divariasi dan dimodernisasi dengan jenis-jenis musik modern. Tarian ini biasanya dilaksanakan pada saat penyambutan tamu atau untuk menghibur raja-raja. Kadang-kadang para penari membawa tempat sirih pinang, yang nantinya diberikan kepada laki-laki untuk kemudian dibalas dengan uang (tatua $k a b i)$. Perlengkapan musiknya terdiri dari gitar dan fiol buatan tangan, disertai dengan nyanyian yang berisi pantun (tsi ma tloel).

Tari kematian (boen nitu atau bonet) dilaksanakan pada waktu ada orang meninggal. Laki-laki dan perempuan berdiri bergandengan tangan, membentuk lingkaran, dan berjalan ke samping dengan sentakan kaki maju mundur. Lagu-lagu serta pantun-pantun yang sedih dilantunkan oleh para ibu untuk mengenang jasa almarhum, kemudian para kaum lelaki menyambutnya dengan teriakanteriakan sedih yang khas. Selama menunggui jenazah, ibu-ibu menumbuk padi dengan irama ketukan lesung dan alu, sambil menyanyikan lagu-lagu sedih yang, disebut mangkalalen.
Tari genderang (likurai) berasal dari Belu dan biasanya dipertunjukkan oleh keturunan yang tinggal di wilayah itu. Tarian ini dilakukan oleh gadisgadis. Sambil menabuh gendang kecil serentak dan berirarna, mereka berjalan sambil melenggak-lenggok, sementara para lelaki menari dengan mengangkat dan memutar-mutar kelewang. Tarian ini biasanya dipertunjukkan pada upacara pesta rumah adat, pada acara penyambutan tamu, atau pada perkawinan adat belis.

\section{Seni Musik}

Selain gong, gitar, bijol, fiol (heo), dan genderang yang digunakan untuk mengiringi tari-tarian, masih ada lagi alat musik yang biasa dibunyikan untuk dinikmati sendiri, antara lain knobe dan feko. Knobe adalah suatu alat musik yang dijepit di antara kedua bibir lalu dipetik sehingga menimbulkan bunyi yang merdu, biasanya dibunyikan kalau orang sedang sendirian di kebun atau di lopo. Feko adalah seruling yang dibuat dari kayu dan ditiup sewaktu menggembalakan sapi di hutan atau di suatu tempat sebagai tanda bahwa dia berada di sana. Alat-alat rnusik juga dimainkan pada saat-saat khusus seperti iris tuak, ikat jagung (loel pena), tiup daun-daunan di hutan ( $p u$ hau no'o), atau sewaktu ari-ari dikeluarkan untuk disimpan di pohon (tapoen olef).

Seni lain yang juga hidup di masyarakat Insana adalah lulai atau rajah tubuh (tato). Kebiasaan ini berasal dari Belu yang kemudian merambah ke Insana. Zat pewarna untuk tato dibuat dari jelaga yang dicampur dengan air perasan batang jagung mentah. Gambar tato seperti motif ukiran. Pada zaman modern 
seperti sekarang ini, nama diri dan nama orang yang disayang biasanya dipilih sebagai salah satu bentuk Iulai atau tato masyarakat Insana. Bagian tubuh yang biasanya dirajah adalah sepanjang lengan sampai bahu, tungkai bawah sampai punggung kaki, dan khusus laki-laki dapat juga dilakukan di bagian dada.

\section{Kerajinan}

Salah satu hasil kerajinan masyarakat Insana yang terkenal adalah tenunan Insana yang memiliki motif dan cara pembuatannya yang khas. Salah satunya adalah bun'a, yaitu cara menenun tais (kain sarung) serta motif-motifnya dengan mengikatkan benangnya seutas demi seutas sehingga penyelesaiannya membutuhkan waktu bulanan sampai tahunan. Jenis lain adalah sotes. Motif sotes hampir sama dengan bun'a. Yang juga khas adalah futus (tenun ikat). Benang-benang diikat dengan selaput daun gebang (kufa) untuk dibuat gambar semisal sapi, ayam, kerbau, buaya, tokek, cecak, dan lain-lain. Kemudian bahan dicelup dalam tarum atau zat pewarna lainnya. Setelah itu ikatan-ikatan dilepas, maka muncullah motif yang tadi digambar dengan latar belakang warna celupan. Dalam tradisi masyarakat Insana, seorang laki-laki dinilai pantas berkeluarga kalau sudah mempunyai ladang sendiri, sedangkan seorang gadis desa dinilai pantas berkeluarga apabila ia sudah dapat menenun selimut atau sarung.

Kerajinan lain adalah anyaman daun lontar untuk berbagai keperluan rumah tangga, seperti tempat sirih pinang, topi, peti, tempat padi, tempat jagung (oko), nyiru (tupa), tempat daging (kasui), dan lain-lain. Di samping itu, ada juga kerajinan tembikar dari tanah liat dalam bentuk periuk, piring, sendok, mangkuk, dan lain-lain. Ukiran tradisional juga dapat dilihat pada pintu-pintu rumah adat, tiang-tiang lopo, tiang agung rumah adat, tempat duduk pada balai-balai di lopo, wadah sirih pinang, sarung dan gagang kelewang, patung, dan lain-lain. Motif ukiran biasanya berupa gambar hewan dan motif dekoratif.

\section{Kearifan Lokal Kerajaan Insana}

Sebagaimana tampak dalam ritus dan mitosnya, masyarakat Insana percaya adanya Tuhan (Uis Neno) yang menciptakan (Alulut, Amo'et), bercahaya dan mernbakar (Apinat, Aklahat), memberi kesejukan dan ketenangan (Manikin Oetene), memelihara dan menumbuhkan (Afatis, Ahaot), yang tempatnya jauh dan tinggi di atas langit (Afinit, Amnanut). Tuhan juga digambarkan sebagai pusat matahari dan bulan sehingga disebut Nenno Anan ma Fuanna Anan. Salah satu hal yang unik, dalam ritus adat ada perhitungan dari angka 1 sampai dengan 7. Angka 7 disebut sebagai milik Tuhan, sedangkan angka 1 sampai 6 diperuntukkan bagi urutanurutan leluhur.

Kepercayaan kepada leluhur sangat kuat. Dalam doa-doa dan mitosmitos, para leluhur biasanya dimintai tolong sebagai perantara (Naetub Natusib Nateab) untuk menyampaikan kepada Tuhan Pengatur dan Pencipta (Alulut, Amo'et). Segala aspek kehidupan di dunia selalu dihubunghubungkan dengan leluhur. Kalau sedang marah, leluhur akan mendatangkan penyakit atau kesialan 
dalam keluarga, atau bahkan akan membiarkan (nasona) keturunannya terkena musibah. Kalau leluhurnya tidak membiarkan (kanfe sona), maka keturunannya akan selamat dan mendapatkan banyak rezeki. Oleh karena itu, peninggalan dan kuburan leluhur selalu dipelihara dan rutin dikunjungi. Pada saat berziarah, orang biasanya membawa hewan persembahan maupun sirih pinang yang diperuntukkan bagi para leluhur.

Nama panggilan (kan niutna) untuk semua cucu selalu diambil dari nama para leluhurnya dengan maksud agar para cucu selalu dilindungi oleh leluhur tersebut. Ada kepercayaan bahwa biasanya sifat dan watak seorang cucu akan menyerupai leluhur yang diambil namanya (tam'na). Nama panggilan ini biasanya didapatkan melalui mimpi orang tuanya.

\section{Upacara Ritual}

Upacara-upacara ritual biasanya diselenggarakan di rumah-rumah adat, baik sonaf (rumah adat para raja) maupun tola (rumah adat amaf). Menurut kepercayaan masyarakat, rumah adat merupakan sumber kehidupan dari seluruh suku (Hit poeka ma hit moenka). Tiap rumah adat mempunyai hau teas di sebelah timurya atau di depannya dengan tumpukan batu-batu datar (bakı) yang jumlah tingkatannya ditentukan menurut aturan adat (nono) suku yang bersangkutan. Bagi sebuah sonaf, tumpukan batu datarnya berjumlah tujuh tingkat. Di dalam rumah adat terdapat tiang-tiang agung, di mana peninggalan para leluhur disimpan atau digantungkan (misalnya tempat sirih pinang atau barang peninggalan lain), dan di bawah tiang agung tersebut ditempatkan juga sebuah batu datar sebagai tempat persembahan serta ternpat mengoleskan darah hewan sembelihan beserta sedikit bulunya (naufna). Di ladang juga dilaksanakan ritus-ritus yang berkaitan dengan siklus bertani, dan biasanya mengambil tempat di sumber air atau di pohon besar yang juga selalu ada hau teas-nya. Macammacam upacara itu berhubungan erat dengan hampir seluruh kegiatan kehidupan manusia, yakni siklus kehidupan, siklus bercocok tanam, upacara rumah adat, dan upacara sonaf.

Upacara siklus kehidupan

Peristiwa-peristiwa penting sejak lahir hingga meninggal senantiasa ditandai dengan upacara adat. Upacara adat yang sangat menonjol dilakukan adalah upacara pada saat melahirkan anak serta mengeluarkan ari-ari dan upacara cukur rambut. Upacara pernikahan (belis) harus dilaksanakan oleh pihak laki-laki supaya bisa membawa pihak perempuan ke rumah adat sukunya (nasaeb nono) dan supaya anak-anaknya nanti berhak memakai nama sukunya (fam). Kalau upacara belis tidak dilaksanakan, maka pihak laki-laki tidak berhak atas anakanaknya, dan anak-anak tersebut akan memakai nama suku ibunya (kawin masuk). Besar kecilnya belis tergantung pada apakah si perempuan keturunan usif atau amaf. Pada umumnya, usif lebih besar belis-nya daripada amaf.

Pada zaman dahulu, belis bagi seorang putri raja terdiri dari beberapa ekor sapi, beberapa ekor kerbau, beberapa ekor kuda, dan sejumlah 
perhiasan emas serta uang perak Belanda (gulden) dan uang emas (sofren), dan bahkan sebidang tanah yang disebut tanah susulaku. Pada masa sekarang, jumlah belis tergantung pada kesepakatan antara kedua belah pihak orang tua, dan lebih disederhanakan, bahkan kadangkadang hanya dengan uang kertas. Dalarn upacara perkawinan, pihak lakilaki (amatsaos) harus mendatangi pihak perempuan (ahonit). Kemudian dilaksanakan upacara kaus nono (melepas adat pihak perempuan) dan menaikkan adat si laki-laki (nasaeb nono). Baru kemudian pengantin perempuan diboyong (tsea) dan diarak ke rumah adat pihak laki-laki untuk diperciki air kepunyaan suku pihak lakilaki, hingga resmilah si perempuan masuk ke dalam suku sang laki-laki (tasusib), yang ditandai dengan melangkah masuk ke dalam rumah adat suaminya.

Apabila seseorang meninggal, terutama bila laki-laki, maka orang akan menunggu sampai seluruh keluarga orang yang meninggal itu hadir lengkap, termasuk anak cucunya. Setelah seluruh keluarga berkumpul, barulah orang yang meninggal boleh dikuburkan. Kalau yang meninggal seorang amaf, maka seluruh tua-tua adat harus hadir, demikian juga para tua-tua dari suku-suku yang berkerabat karena hubungan perkawinan (ahonit, fatson). Kalau penguburan dilangsungkan tanpa kehadiran mereka, maka keluarga yang berduka akan dikenai denda oleh suku ahonit dan fatson tersebut. Kalau yang meninggal seorang usif, maka seluruh suku amaf harus lengkap hadir bersama-sama usif-nya yang ada hubungan, baik bawahan dan atasannya maupun usif-usif tetangganya. Terlebih lagi pihak yang berkerabat karena hubungan perkawinan harus ditunggu kehadirannya. Hal ini menyebabkan kadang-kadang jenazah disemayamkan selama berhari-hari bahkan berbulanbulan. Dalam masa penantian itu, ditampilkan tari bonet (boen nitu) serta upacara tumbuk padi tiap malarn yang disebut mangkalalen. dengan melantunkan syair-syair dan pantunpantun kedukaan. Orang-orang juga melewatkan waktu dengan melakukan permainan kuru-kuru (dadu) dan ikat ayam. Selama itu, semua yang hadir diberi makan dan minum sehingga banyak ternak yang harus disembelih.

Ungkapan belasungkawa selalu disertai dengan ratapan pilu para ibu dan disertai dengan pemberian kain Timor (tais, beti) sebagai selimut bagi yang meninggal. Uang perak dibawa serta untuk dimasukkan ke dalam peti mayat. Semua ini dipercayai akan menjadi bekal bagi si arwah pada kehidupannya di alam yang lain. Pada saat penguburan, dilaksanakan upacara menurunkan hak keluarga kepada anak laki-laki tertua (nesan nabal, tapan nain), serta upacara hak raja atau hak amaf yang disebut piul (diberi destar). Sesaat setelah penguburan, dilaksanakan upacara mengirim bekal (afta nok tutu kubi, polen kubi), serta upacara nasaeb banlet a agar jangan sampai anggota keluarga lain dibawa serta oleh arwah yang meninggal.

Upacara siklus bercocok tanam

Rangkaian upacara bercocok tanam dimulai dari persiapan kebun 
hingga panen. Urut-urutannya sebagai berikut; upacara mempersiapkan kebun (ta'nelat hun mau), upacara membalik tanah (tnonop suan), upacara mengeluarkan bibit tanaman (tapoen fini buke), upacara agar tanarnan tumbuh subur dan tidak dirusak hama (eka hoe), upacara makan jagung muda (talila pen a sufan, sainna koen), upacara panen (eka pen a smanan ma anne smanan), upacara bentang tikar (tabena nahe), upacara ikat jagung (fut pena) yang disertai dengan lagu-lagu dan syairnya, serta upacara tutup lumbung (taeka lopo). Di samping itu, masih ada upacara mendinginkan tanah (sifo nopo) pada saat menebas hutan baru. Semua upacara itu dilaksanakan dengan tujuan agar kebun atau ladang terhindar dari hama dan bencana, dan diharapkan nantinya memberikan hasil yang baik. Pelaksana semua upacara itu adalah tobe, yang selalu memberitahukan kapan, di mana, dan bagaimana pelaksanaannya kepada seluruh masyarakat di wilayah yang menjadi tanggung jawabnya.

Pada saat kemarau atau ketika hujan tidak turun pada saat tanaman telah tumbuh, dilangsungkan upacara paceklik (toet upu timo). Upacara ini dilangsungkan di atas puncak bukit Maubes. Sebelumnya, suku Abainpah mengabarkan kepada suku-suku uis neon mes ina (raja sehari), yaitu Kofi Saunoah, Finsau, Lamasi, dan sukusuku tua, yaitu Saban Tasoe-Muna Oeleu (Bah mau tui mau, poho nehe), untuk bersama berkeliling dan mengabari seluruh usif dan amaf di kerajaan Insana untuk berkumpul dan melaksanakan upacara paceklik tersebut.
Setelah semua suku amaf dan usif berkumpul, maka suku Abainpah menyiapkan seekor kerbau belang untuk dipersembahkan. Kerbau tersebut hanya diikat dengan seutas benang putih, lalu ditarik naik ke puncak bukit Maubes. Di sana kerbau tersebut disembelih tengkuknya oleh wakil semua suku yang hadir. Bagianbagian tubuh kerbau dipersembahkan kepada leluhurnya atupas, dan Tuhan (Alulut, Amoet, Apakaet) dengan disertai doa adat, lalu daging kerbau tersebut dimakan dengan nasi oleh semua yang hadir. Karena daging itu tidak boleh dibawa pulang ke rumah, maka apabila tidak habis dimakan, sisa makanannya harus ditinggalkan. Seusai upacara, seekor ayam jantan merah dan seekor kambing jantan diikat di atas pohon dan ditinggalkan di situ hingga mati. Upacara ini biasanya dipimpin oleh amaf mnasi (Saban, Tasoe, Muna, Oeleu). Orang percaya, sesaat setelah upacara tersebut dilangsungkan hujan akan segera turun.

Setelah panen, biasanya menjelang musim tanam berikutnya, dilaksanakan upacara penyerahan upeti (maus) kepada atupas. Dari setiap kepala keluarga dikumpulkan tujuh bulir jagung dan satu tanasak padi oleh tobe masing-masing suku. Selanjutnya, maus tersebut diantarkan kepada tua adat suku, dan disalurkan melalui hierarki suku-suku dan jalur yang telah ditentukan, yaitu dari amaf tersebut ke amaf naek (kapitan), yang kemudian berhimpun di usif tnana (usif kecil); di sana bagian untuk usif tnana ditinggalkan, dan selanjutnya ke usi naek (moen le'u atoin le'u), kemudian selebihnya akan dibawa ke sonaf, yakni

Jurnal IImu Sosial dan Humaniora | 128 
rumah adat atupas. Setelah lengkap dari semua suku dari satu wilayah (Eno), maka bersama-sama dengan usif besar dan para suku penerang (pa'uk pinfa), mereka mendatangi sukusuku pemagar (bilu bahan). Di wilayah timur mereka sampai ke suku Kofi, Finsau, dan di sebelah barat sampai ke Lamasi dan Saunaoh. Kemudian mereka menghampiri suku-suku poho nehe, yaitu Saban Tasoe, Muna Oeleu (bah mau tui mau) untuk diantar kepada para amaf dalam. Dari timur mereka ke amaf Mataufina dan Nai Tkakin. Dari barat mereka ke amaf Banusu Dalam dan Nopala. Ketika sampai di suku-suku amaf dalam tersebut, maus disimpan dan dijaga (bea' na ma nanu'ba). Sementara itu, kesenian tradisional (bso'ot, bidu) dipertunjukkan, sementara para tua-tua adat mengisahkan tutur adat tentang riwayat suku-suku dan Sonaf Insana sebagai pemilik tanah serta segala isinya.

Selanjutnya, pada hari yang telah ditetapkan diantarlah maus tersebut ke Sonaf Insana dan di sana telah dipersiapkan upacara penerimaan oleh atupas dengan disertai makan minum (siom manikin-oetene). Pada masa sekarang, upacara-upacara yang berkaitan dengan siklus tanaman tersebut sudah jarang dilakukan. Hanya beberapa tua adat dari suku-suku tertentu yang masih mempertahankannya. Begitu juga upacara upeti (maus) hanya dilaksanakan oleh beberapa suku kalau mereka mengalami paceklik, terserang hama, atau gagal panen.
Upacara rumah adat

Setiap suku, baik usif maupun amaf mempunyai rumah adat. Di rumah adat tersimpan barang-barang peninggalan para leluhur, maka rumah adat dipercayai merupakan sumber kekuatan dan sumber kehidupan (hit poeka ma hit ua'kma hit ma'tanek) serta sumber kesejukan (nunha mafon ma lette mafon) bagi seluruh warga suku tersebut. Rumah adat usif disebut sonaf (istana) atau baaf (akar). Rumah adat amaf disebut uam le'u (rumah keramat) atau tola (tempat berkumpulnya seluruh keturunan). Barang-barang keramat $(l e ' u)$ yang disimpan di dalam rumah adat antara lain tempat sirih pinang semua leluhur, perhiasan-perhiasan para leluhur seperti; mahkota, tongkat, gelang, cincin, dan perhiasan emas lainnya, perlengkapan perang seperti; senapan tumbuk, pistol, kelewang, panah, parang, dan lain-lain, peninggalan-peninggalan lain seperti; piring, mangkuk, sendok, suling, gong, pelana, giring-giring dan lain-lain yang pernah digunakan oleh leluhur.

Pusat rumah adat adalah Sonaf Insana. Sonaf Insana, yang juga disebut Baaf, adalah rumah adat ternpat tinggal atupas. Sang atupas tinggal di suatu kamar di atas balaibalai tinggi (hala mnanu). Rumah adat ini berbentuk bulat dengan sebuah pintu di utara sebagai pintu perempuan (neus feto) dan sebuah pintu di timur sebagai pintu laki-laki (neus atoni). Tiang utamanya ada dua buah, satu di timur yang disebut Tiang Liurai ( $\mathrm{Ni}$ Liural), dan satu lagi di sebelah barat yang disebut Tiang Sonbay (Ni Sonbay). Kedua tiang agung tersebut juga disebut Ni Anpupu-Ni Anmatani, sedangkan kayu penghubung di bagian 
bubungan atap disebut Afinit ma Amnanut. Setiap tiang agung disangga oleh empat buah kayu penyangga yang melambangkan bahwa setiap usif selalu didukung oleh empat kelompok suku usif dan empat kelompok suku amaf. Di dalam rumah adat tersebut ada dua buah balai-balai, yakni balaibalai tinggi untuk tempat duduk atupas, yang di sampingnya ada kamar tempat atupas bersemayam, dan balai-balai rendah untuk tempat duduk para usif kalau sedang berternu atupas. Di sekitar tiang agung diletakkan perlengkapan-perlengkapan perang, seperti senapan tumbuk, tongkat kerajaan, pistol, kelewang, suling, terompet, dan lain-lain. Di atas loteng dekat ujung tiang agung diletakkan tempat-tempat sirih pinang, perhiasan, dan barang-barang keramat $(l e ' u)$.

Di pelataran di depan pintu timur ada hau teas atau hau monef yang bercabang tiga, dan di atasnya ada sebuah batu datar. Pada pangkal hau teas disusun batu-batu (bakı) bertingkat tujuh. Hau teas merupakan tempat mengambil kekuatan dan daya hidup bagi seluruh keluarga Usfinit maupun seluruh rakyat Insana. Di depan Sonaf Insana ada Lopo Naek atau Lopo Matolas, yang merupakan tempat berlangsungnya musyawarah adat yang juga mempunyai balai-balai tinggi dan rendah. Lopo Naek juga digunakan sebagai tempat menyimpan upeti dari seluruh rakyat. Upacara rumah adat biasanya dilaksanakan setelah diadakan renovasi bangunan. Upacara adat ini merupakan suatu pesta besar yang harus dihadiri oleh seluruh kerabat dan keluarga yang berasal dari rumah adat tersebut. Oleh karena rurnah adat merupakan pusat dan akar dari seluruh suku, baik usif maupun amaf, maka semua orang harus hadir untuk mendapatkan rahmat dan kekuatan (tapen ma'tanek ma manikin oetene).

Sesuai kebiasaan dan adatistiadat, setiap keturunan dan seluruh rakyat diharapkan membawa persembahan berupa sirih pinang untuk dimasukkan ke dalam tempat sirih pinang para leluhur, dan membawa hewan kurban untuk disembelih di hau teas. Menurut kepercayaan, semua anak cucu dan seluruh rakyat wajib mernberikan persembahannya dan sekaligus untuk mendapatkan rahmat, rezeki, dan penghidupan yang baik di waktu-waktu yang akan datang. Hal ini menyebabkan kadang-kadang jumlah hewan yang disembelih sangat banyak. Pada masa sekarang, karena pertimbangan ekonomis, upacara tersebut telah disederhanakan dengan dibagi dalam kelompok-kelompok, seperti kelompok anak, kelompok cucu, dan kelompok anak perempuan, di mana masing-masing kelompok membawa seekor hewan saja.

Dalam setiap acara pertemuan adat, sopi (arak) yang diistilahkan oe maputu (air panas) harus selalu disediakan. Sopi merupakan tanda perdamaian untuk diminum bersama (tium ma tois tua, nok in suanna). Selama beberapa hari pelaksanaan upacara rumah adat, masing-masing keturunan dan suku-suku rakyat mempertunjukkan kesenian tari-tarian bidu, likurai, dan lain-lain. Saat ini rumah adat digunakan juga sebagai tempat untuk berdoa. Setiap upacara adat selalu didahului dengan doa secara agama Katholik dan kemudian dilanjutkan dengan doa secara adat. 
Sejak diresmikan terakhir kalinya pada tahun 1993, rumah adat juga diberkati oleh pastor sehingga pada tiang agung dipasang salib dan patung Bunda Maria serta Kitab Suci.

Adat Istiadat

Mitos sebagai landasan idiil

Masyarakat Insana percaya akan adanya Tuhan (Uis Neno) yang mempunyai sifat-sifat sangat tinggi dan jauh dari jangkauan (Anesit Amnanut); pusatnya matahari dan bulan (Neno Anan, Fuana Anan); pencipta dan pemelihara (Alulut, Amoet, Apakaet); bercahaya dan membakar (Apinat, Aklahat). Berdasarkan ungkapanungkapan tersebut, yang selalu diucapkan dalam mitos dan ritus masyarakat Insana, dapat disimpulkan bahwa mereka percaya akan Tuhan Yang Maha Kuasa, di mana di dalam doa-doa mereka pada saat melaksanakan upacara-upacara adat mereka selalu meminta tolong kepada para leluhur, untuk menyampaikan atau meneruskan doa-doanya kepada Tuhan supaya permohonan mereka dapat dikabulkan.

Kepercayaan masyarakat kepada leluhur juga sangat kuat, Menurut kepercayaan, orang yang meninggal hanyalah berpindah tempat ke alam gaib, sehingga para leluhur harus tetap dihormati, dipelihara segala peninggalannya, dan diberikan bekal. Nasib semua keturunan dipercayakan sepenuhnya kepada para leluhurnya, yang telah dekat dengan Tuhan. Oleh karena itu, kalau seseorang mendapat celaka atau sial, biasanya peristiwa itu dihubung-hubungkan dengan leluhurnya yang marah, atau memberi peluang (nasona) untuk masuknya setan atau suanggih. Kepercayaan terhadap mimpi juga sangat kuat. Kadang dari suatu mimpi, dapat ditafsirkan bahwa leluhur menghendaki anak cucunya yang masih berada di dunia melakukan sesuatu bagi mereka.

Nama leluhur dianggap sakral sehingga orang takut keliru mengucapkannya. Kalau seseorang salah menyebutkan silsilah atau nama rajanya, konon yang bersangkutan bisa meninggal sesaat kemudian (tefan fain). Masyarakat Insana percaya bahwa raja (usif) adalah keturunan Tuhan sehingga disebut Uis Neno Ana (Anak Tuhan). la disebut Neno (langit) dan Malafu (bintang) sebab bintang adalah anak dari perkawinan matahari dan bulan. Tanah dan semua isinya adalah milik raja sebagai pemilik tanah (pah tuafa), yang kemudian dibagikan kepada suku-suku, sehingga hasilnya harus diserahkan kepada raja dalam rupa upeti. Baru sisanya untuk rakyat.

Kepercayaan terhadap kekuatan gaib juga ada, khususnya terhadap barang atau tempat yang dikeramatkan $\left(/ e^{\prime} u\right)$. Ada dua macam kekuatan, yakni kekuatan baik dan kekuatan jahat. Yang baik memakai kekuatan gaib untuk keberanian berperang, menyembuhkan penyakit, ataupun kemampuan-kemampuan supranatural lainnya, seperti mendatangkan hujan dan menghentikan hujan, dan lain-lain. Yang jahat, disebut suanggih, memakai kekuatan gaib untuk mencuri, menipu, membunuh, dan lain-lain. Masyarakat Insana juga mempunyai nuni atau tabu, yaitu larangan atau pantangan melakukan sesuatu. Setiap suku mempunyai aturan adat tersendiri, yang disebut nono atau tusi yang harus ditaati oleh seluruh anggota suku yang 
bersangkutan. Kalau nuni dan nono dilanggar, dipercaya bahwa si pelanggar akan terkena penyakit atau musibah. Sehubungan dengan itu, ada cara-cara adat untuk memulihkan seorang anggota keluarga yang terkena musibah akibat melanggar nuni atau nono.

Ritus sebagai landasan prosedural
Mitos dan kepercayaan masyarakat diungkapkan dalam wujud tindakan ritual. Seperti telah diungkapkan, peristiwa penting siklus kehidupan manusia dan kegiatan keseharian selalu ditandai dengan upacara adat, untuk mendapat kehidupan yang lebih baik ataupun yang sifatnya menolak bala. Upacaraupacara adat biasanya dipimpin oleh suku yang rnempunyai tugas untuk itu atau oleh tua adat yang telah ditentukan. Upacara didahului dengan doa adat di hau teas atau tiang agung di dalam rumah adat, di mana telah dipersiapkan terlebih dahulu sirih pinang, sopi, hewan kurban, serta uang perak. Setelah doa adat (toe), maka hewan kurban disembelih, kemudian tua adat akan melihat jeroannya (hati, limpa, usus) lalu menafsirkan tandatandanya (tae sulat) yang berarti membaca surat. Kalau didapatkan tanda yang tidak baik, maka harus dilakukan tindakan perbaikan supaya tidak datang musibah di kemudian hari. Setelah itu, bagian-bagian tertentu dari hewan kurban (hati, limpa, daging has, dan dada serta paha ayam) dimasak secara terpisah, yang kemudian akan dipersembahkan kembali kepada para leluhur di hau teas atau tiang agung dengan satu nyiru nasi, yang disebut tekes. Setelah didoakan, tekes dimakan bersama sampai habis oleh tua-tua adat dan anak cucu yang mengikuti doa adat tadi, sambil minum sopi bersama.

Menurut kepercayaan, tekes adalah makan bersama dengan para leluhur, sehingga daging yang dimakan tidak boleh terjatuh. Makanan jatuh berarti tanda akan datangnya musibah. Sirih pinang dan uang perak disimpan pada tempat sirih pinang leluhur (aluk nok kabi) dan sebagian sirih pinang dibagikan kepada para tua adat dan para cucu yang hadir agar mendapatkan kekuatan dan rahmat. Daging yang lainnya akan dimasak dan selanjutnya dimakan bersama (ta'nama, siom seat) oleh seluruh hadirin. Dalam acara makan bersama ini, biasanya kaum laki-laki yang terlebih dahulu mengambil, baru kemudian diikuti oleh kaum ibu dan anak-anak. Tata cara makan bersama ini dilaksanakan dengan duduk bersila, di mana para usif duduk di balai-balai tinggi dan para amaf di balai-balai rendah. Kadang-kadang satu ekor babi, yang hanya dikeluarkan jeroannya saja, diberikan kepada seseorang yang dipandang terhormat oleh tuan pesta. Penghormatan ini harus dibalas kembali oleh si penerima dengan nilai yang sepadan dengan pemberian tersebut pada saat ia mengadakan pesta adat di tempatnya (ta'nakab atau tait faft nakaf).

Selama rnakan, hadirin dilayani oleh para pelayan (abilut abso'ot). Pada setiap upacara atau pesta adat, untuk rajanya, entah hadir entah tidak, selalu disiapkan sajian tersendiri, yang biasanya berupa paha depan (tnapu atau belo benan) dari hewan kurban. Di samping doa (toe), persembahan (tekes), dan makan bersama (ta'nama) 
ini, ada pula acara-acara tambahan sesuai dengan jenis upacaranya, baik sebelum maupun setelah inti upacara.

Suku sebagai landasan struktural

Pusat kerajaan Insana (paha usan) dikelilingi oleh para usif dan amaf, yang berpasang-pasangan (mabia-mabia) dalam susunan yang disebut quadro partition $(2+2=4)$. Suku-suku tersebut tersusun mengelilingi Usfinit di tengah-tengah, mengarah ke semua penjuru mata angin. Setiap satu wilayah mata angin (eno) dikuasai oleh kelompok usif dan amaf tertentu. Dalam tutur adat, penyebutan suku-suku selalu didahului oleh pasangan pertama dan kemudian diikuti pasangan lainnya. Sebagai contoh, untuk usif selalu dipasangkan Us Fal dengan Us Taolin, Us Pupu dengan Us Tonbes. Untuk amaf dipasangkan Nopala dengan Mataufina, kemudian Tkakin dengan Banusu. Hubungan antara suku-suku yang berpasang-pasangan ini berdasarkan tali persaudaraan, tali perkawinan, ataupun karena tugas yang sama.

Kedudukan, fungsi, serta tugas dari suku-suku, sesuai dengan mitos, ritus, dan struktumya, dibedakan atas raja (usif), suku-suku (amaf), dan rakyat (kolo manu).

1) Raja: usif tertinggi di pusat, raja-raja besar dalam, raja-raja besar luar, raja-raja tengah, raja-raja penguasa wilayah, raja-raja kecil, raja-raja penerang, dan raja-raja sehari.

2) Suku-suku (amaf): suku-suku besar (ama naek), suku pendamping (nefu hala, kanaf), suku kecil (ameput), pengatur tanah (tobe kalili), bala tentara (meo sapan), panglima perang (meo naek).
3) Rakyat: rakyat biasa (kolo manu), hamba (abe'at, ate), dan lain-lain.

Biasanya dari nama suatu suku dapat digambarkan tugas dan fungsi suku tersebut, hanya kadang-kadang diberi tugas tambahan. Besar kecilnya seorang raja atau seorang amaf dapat diketahui dari jumlah suku yang menyangganya. Makin besar raja atau amaf tersebut, semakin banyak suku yang menyangga atau mengelilinginya. Secara garis besar, kerajaan Insana rnempunyai struktur sebagai berikut.

1) $\mathrm{Di}$ tengah-tengah adalah Usfinit yang bergelar Atupas, Kesel, Maubes Tuan, atau Raja Tertinggi.

2) Di wilayah dalam di sekeliling Usfinit terdapat empat suku raja besar dalam (naiju mone nanna) yaitu Kolne, Abainpah, Manikin, Maun Naijuf, dan empat suku besar amaf dalam (asani anako) yaitu Nopala, Mataufina, Nai Tkakin dan Banusu Dalam.

3) Di wilayah luar di setiap penjuru mata angin terdapat empat suku raja besar luar (naiju mone moen 'a) yaitu Us Fal, Us Taolin, Us Pupu, Us Tonbes, dan empat suku besar amaf luar (ama naek moen'a): Nai Hitu, Nai Taboy, Nai Saijao, Nai Banusu.

4) Di wilayah antara luar dan dalam, di antara kelompok usif serta amaf luar dan kelompok usif serta amaf dalam, terdapat suku-suku yang disebut bilu bahan (pemagar) yaitu Kofi, Saunoah, Finsau, dan Lamasi. Di sebelah barat terdapat suku-suku tua (bah mau tui mau) yang berfungsi sebagai penjaga pintu dan harus dihampiri (poho nehe), yaitu Saban, Tasoe, Muna, Oeleu.

Di samping itu masih ada lagi suku-suku berikut ini:

Jurnal IImu Sosial dan Humaniora| 133 
1) raja penguasa wilayah (usi tnana) atau usif tengah, misalnya Anapah, Ataupah, Afeanpah, Abainpah;

2) raja kecil yang berdiam di antara para amaf, misalnya Noe Tnana, Laemfaun, Tnekleu, Ahoinpah, Us Subun, dan lain-lain;

3) raja penerang (paku pinaf), misalnya Taku-Talua, Akunut-Asolan;

4) panglima perang, misalnya Kase Tahmate, Sumu Taslulu (meo naek) di Eno Banusu, dan lain-lain.

Masih ada suku lain yang disebut raja-raja menetap (uis pah bal ina), di mana peran mereka dihilangkan. Ada pula yang pindah ke kerajaan lain seperti Balnai, Tefnai, Kisnai, Ahoinnai. Di pihak lain, di kerajaan Insana datang juga raja-raja dari kerajaan Miomaffo, yaitu Us Kono dan Us Olin beserta para amaf-nya, yaitu Kefi-Finit dan SauAnunut. Setiap suku mempunyai identitas yang khas antara lain dalam hal-hal berikut:

1) wilayah teritorial atau tanah kekuasaan (in naijan in palh ma in nifu);

2) rumah adat (tola), yaitu sonaf le'u bagi usif dan uam le'u bagi amaf;

3) sumber air (oela atau oe makana), yang dikeramatkan;

4) pohon dan tempat keramat (hau le'u dan bale mnasi le'u);

5) bukit batu dan gunung (fatu makana dan nu makana);

6) aturan atau tata cara adat (nono atau tusi);

7) larangan atau pantangan (nuni);

8) cap atau tanda suku (malak) dan hetes yaitu memotong kuping ternak peliharaan, pada zaman dahulu malak dipakai sebagai semacam tanda pengenal suatu suku.
Di samping ritus, mitos, dan struktur kesukuan yang mempengaruhi kehidupan maupun adat-istiadat masyarakat Insana, beberapa hal khas lainnya adalah cara berpakaian dan tata cara duduk dalam upacara adat. Pada acara-acara adat, untuk membedakan antara usif dan amaf, dapat dilihat dari bentuk ikat daster dan selendang yang disandang, yakni usif menyandangnya di bahu, sedangkan amaf mengikatnya pada pinggang. Amaf duduk bersila (bai'ke) dan berjalan merunduk (taneltok) di acaraacara adat, yang berbeda dengan usif.

\section{SIMPULAN DAN SARAN}

Berdasarkan hasil penelitian dan pembahasan tentang budaya dan kearifan lokal kerajaan Insana yang ada di dataran Timor, dapat disimpulkan bahwa kebudayaan dan kearifan lokal yang ada di kerajaan Insana cukup beragam. Dari segi budaya, terdapat beberapa kesenian dan kerajinan yang ada di kerajaan Insana. Dari unsur kesenian, kerajaan Insana mempunyai seni tari yang terdiri dari; tari perang (tabso, bso'ot), tari bidu (biul), tari kematian (boen nitu atau bonet), tari genderang (likurai). Selanjutnya dari unsur seni musik kerajaan Insana mempunyai beberapa alat musik tradisional yang biasa dipakai pada acara adat atau sebagai pengiring tarian adat diantaranya; gong, gitar, bijol, fiol (heo), genderang, knobe dan feko. Selain seni tari dan seni musik, kerajaan Insana juga mempunyai satu bentuk kesenian yang cukup menarik yaitu lulai atau rajah tubuh (tato). Zat pewarna untuk tato dibuat dari jelaga yang dicampur dengan air perasan batang jagung mentah dengan gambar 
tato seperti motif ukiran. Selain kesenian, masyarakat Insana juga memiliki budaya kerajinan. Salah satunya adalah tenunan (kain tenun). Ada beberapa jenis kain tenun yang dibuat oleh masyarakat Insana yaitu bun'a, cara menenun tais (kain sarung), sotes, dan futus. Dalam tradisi masyarakat Insana, seorang laki-laki dinilai pantas berkeluarga kalau sudah mempunyai ladang sendiri, sedangkan seorang gadis desa dinilai pantas berkeluarga apabila ia sudah dapat menenun selimut atau sarung.

Kerajinan lain adalah anyaman daun lontar untuk berbagai keperluan rumah tangga, seperti tempat sirih pinang, topi, peti, tempat padi, tempat jagung (oko), nyiru (tupa), tempat daging (kasui), dan lain-lain. Di samping itu, ada juga kerajinan tembikar dari tanah liat dalam bentuk periuk, piring, sendok, mangkuk, dan lain-lain. Ukiran tradisional juga dapat dilihat pada pintu-pintu rumah adat, tiang-tiang lopo, tiang agung rumah adat, tempat duduk pada balai-balai di lopo, wadah sirih pinang, sarung dan gagang kelewang, patung, dan lain-lain. Motif ukiran biasanya berupa gambar hewan dan motif dekoratif.

Ragam budaya yang ada pada masyarakat Insana juga telah melahirkan kearifan lokal yang sudah diwariskan tutun temurun. Kearifan lokal tersebut dapat terlihat pada upacara ritual dan tradisi yang menjadi adat istiadat masyarakat Insana. Upacara ritual biasanya diselenggarakan di rumah-rumah adat, baik sonaf (rumah adat para raja) maupun tola (rumah adat amaf). Upacara ritual pada kerajaan Insana terdiri dari (a) upacara siklus kehidupan yang berkesinambungan sejak lahir hingga meninggal, (b) upacara siklus bercocok tanam mulai upacara mempersiapkan kebun (ta'nelat hun mau), upacara membalik tanah (tnonop suan), upacara mengeluarkan bibit tanaman (tapoen fini buke), upacara agar tanarnan tumbuh subur dan tidak dirusak hama (eka hoe), upacara makan jagung muda (talila pen a sufan, sainna koen), upacara panen (eka pen a smanan ma anne smanan), upacara bentang tikar (tabena nahe), upacara ikat jagung (fut pena), upacara tutup lumbung (taeka lopo), upacara mendinginkan tanah (sifo nopo) pada saat menebas hutan baru, serta (c) upacara rumah adat yang dilaksanakan di rumah adat usif maupun amaf. Rumah adat usif disebut sonaf (istana) atau baaf (akar). Rumah adat amaf disebut uam le'u (rumah keramat) atau tola (tempat berkumpulnya seluruh keturunan).

Dalam adat istiadat, kearifan lokal pada kerajaan Insana tercermin dari (a) mitos sebagai landasan idiil yang menunjukkan masyarakat Insana percaya akan adanya Tuhan (Uis Neno) yang mempunyai sifat-sifat sangat tinggi dan jauh dari jangkauan (Anesit Amnanut); pusatnya matahari dan bulan (Neno Anan, Fuana Anan); pencipta dan pemelihara (Alulut, Amoet, Apakaet); bercahaya dan membakar (Apinat, Aklahat), (b) ritus sebagai landasan prosedural yang ditunjukkan dalam peristiwa penting siklus kehidupan manusia ataupun kegiatan keseharian yang selalu ditandai dengan upacara adat, untuk mendapat kehidupan yang lebih baik ataupun yang sifatnya menolak bala, serta (c) suku sebagai landasan 
struktural yang ditunjukkan dalam kedudukan, fungsi, serta tugas dari suku-suku, sesuai dengan mitos, ritus, dan strukturnya, dibedakan atas raja (usif), suku-suku (amaf), dan rakyat (kolo manu).

Selain yang sudah disebutkan sebelumnya, masih banyak hal menarik lainnya yang dapat digali selain budaya dan kearifan lokal di kerajaan Insana. Oleh karenanya, peneliti berharap kajian atau penelitian lain mengenai kerajaan Insana sebagai sebuah warisan budaya di tanah Timor semakin banyak dilakukan. Hal ini perlu sebagai upaya untuk menjaga dan mendokumentasikan salah satu kekayaan budaya nusantara agar tak punah termakan waktu.

\section{UCAPAN TERIMA KASIH}

Peneliti mengucapkan terima kasih kepada Direktur Riset dan Pengabdian Masyarakat Kementerian Riset dan Teknologi (Badan Riset dan Inovasi Nasional) yang telah membiayai seluruh kegiatan penelitian ini. Selain itu, penulis juga mengucapkan terima kasih kepada LPPM Universitas Timor yang telah membantu pada setiap tahapan penelitian ini sehingga penelitian ini dapat selesai tepat waktu. Tak lupa peneliti juga mengucapkan terima kasih kepada masyarakat kerajaan Insana dan semua pihak yang terlibat dan berkontribusi dalam penelitian ini dari awal hingga akhir. Terima kasih.

\section{DAFTAR PUSTAKA}

Aminudin. 2013. Menjaga Lingkungan Hidup dengan Kearifan Lokal. Bandung: CV Titian IImu.
Arikunto, S. (2003). Manajemen Penelitian. Jakarta: PT. Rineka Cipta.

Azis, W. (2017). Data Arkeologis Pendukung Keberadaan Pelabuhan Kuno Wini, Timor Tengah Utara, Nusa Tenggara Timur. Skripsi. Fakutas Ilmu Budaya Universitas Gajah Mada: Tidak diterbitkan.

Bungin, B. (2003). Analisis Data Penelitian Kualitatif, Pemahaman Filosofis dan Metodologis ke Arah Penguasaan Model Aplikasi. Jakarta: PT. Raja Grafindo Persada.

Dethan, R. A. \& Setiawan, A. P. (2014). Studi Bentuk Dan Fungsi Ruang Pada Istana Raja (Sonaf) Di Desa Oelolok Kecamatan Insana Kabupaten Kefamenanu - Nusa Tenggara Timur. Jurnal Intra, 2(2).

Kanisius, S. K. (2014). Filsafat Lingkungan Hidup, Alam sebagai Sebuah Sistem Kehidupan. Jakarta: Rineka Cipta.

Miyake, F. \& Bellamy, J. (2013). Ekologi Marx; Materialisme dan Alam, Terjemahan. Pius Ginting. Jakarta: Walhi.

Soekanto, S. (2006). Sosiologi: Suatu Pengantar. Jakarta: Raja Grafindo Persada.

Sukmadinata, N. S. (2008). Metode Penelitian Pendidikan. Bandung: PT. Remaja Rosdakarya.

Suparman, U. (2017). Eksistensi Kearifan Lokal sebagai Perekat Budaya dan Bangsa. Prosiding. Kegiatan IImiah Tingkat Nasional kearifan Lokal dalam Dinamika Masyarakat Multikultural. Bandar Lampung: Lembaga Penelitian

Jurnal IImu Sosial dan Humaniora | 136 


$$
\text { dan Pengabdian Kepada }
$$
masyarakat Universitas Lampung.

Syani, A. (2013). Menumbuhkan Kembali Nasionalisme Melalui Nilai-nilai Kearifan Lokal. Lampung: http://staff. unila. ac. id/abdulsyani/2013. Diakses tanggal 19 Juni 2019.

Usfinit, U. A. (2003). Maubes Insana: Salah Satu Masyarakat di Timor dengan Struktur Adat yang Unik. Yogyakarta: Penerbit Kanisius.

Wagiran. (2012). Pengembangan Karakter Berbasis Kearifan Lokal Hamemayu Hayuning Bawana (Identifikasi Nilai-nilai Karakter Berbasis Budaya). Jurnal Pendidikan Karakter. Tahun II, Nomor 3. 